\title{
Canadian Immigration: Recent Developments and Future Prospects*
}

\author{
BY ANTHONY H. RICHMOND
}

Canada has a population of 22.5 million people inhabiting nearly four million square miles of territory. Geographically, it is the largest country in the Western Hemisphere and the second largest in the world. This has led many people to regard it as underpopulated and capable of absorbing a vastly increased population. However, this expansionist view is now being seriously questioned. It is recognized that much of the land is mountainous or subject to an arctic climate that makes it inhospitable to settlement. The developed land is not more than one-third of the total and permanent settlement makes up only about 10 per cent of the total area. The large majority of the population of Canada lives along a narrow strip within 650 miles of the American border. One area of continuous settlement, within $\mathbf{2 7 0}$ miles of the U.S. border, is only 2.2 per cent of the area of Canada, but contains its eight largest cities and 36 per cent of the population, (Canada Year Book, 1973: 1). Overall, Canada's average population density ranks among the lowest in the world at approximately six persons per square mile in 1971. However, on the basis of density per square mile of occupied agricultural land, it is 79 per square mile. The provinces of Ontario and Quebec come closer to the densities of Europe as a whole, being nearer to 290 per square mile. However, even the large cities and metropolitan areas of Canada are not as heavily populated as the major urban conurbations of Britain and Europe, (Kubat and Thornton, 1974: 6).

From the beginning of European settlement in the early 17th century, natural increase and net immigration have both contributed to a rather rapid growth of population; Canada is now more than seven times its size as the first census in 1871. A distinctive feature of the Canadian population is the persistence of a French speaking proportion of a little under one-third. Until recently, the growth of this Francophone population of Canada was attributable mainly to a high rate of natural increase, and very little to net migration. Immigration was more important in maintaining the growth of the rest of the population, mainly of British and other European ethnic origin, whose birth rates, until recently, were much lower than those of French Canadians. The annual growth rate of the Canadian population reached a peak of 3.3 per cent per annum in 1956-1957. (Kalbach and McVee, 1971: 31-69). Between 1961 and 1971 the growth rate averaged 1.7 per cent per annum falling to 1.2 per cent in 1971-1972. It has risen slightly since then as a consequence of some increase in net migration.

- Paper presented at a conference on 'Comparative Research on Migration Policy' under the auspices of Institut fur Empirische Sozialforschung (IFES) Austria and the Research Committee on Migration of the International Sociological Association, Vienna 5-9 May, 1975. 
Future growth will depend upon both fertility and migration trends. The gross reproduction rate has now fallen below the replacement level; it was 0.937 in 1973, (Vital Statistics, 1974: 13). It is not known whether this trend will be maintained or whether this represents a deferment of births by some young couples. However, a fertility rate close to the replacement level does not mean that Canada will soon reach zero population growth. Even if immigration ceased, it is estimated that the population would continue to grow until about the year 2040. This is due to the high proportion of young women in the child bearing age groups, (Population Projections, 1974: 64).

The contribution of immigration to population growth is the net result of both inward and outward movements. Between 1946 and 1971, Canada admitted approximately three and a half million immigrants, ostensibly for permanent settlement, but only 2.3. million were still resident at the time of the census, (1971 Census of Canada, 1974: Advance Bulletin 9: 1). At the same time, there was some emigration of those born in Canada. Unfortunately, accurate statistics of outmigration from Canada are not available. Between 1951 and 1961, the net gain by migration was a little over one million, compared with only 722,000 in the decade up to 1971 . On this basis, net migration contributed only 21.7 per cent of the total growth in the decade, (Canada Year Book, 1973: 208). Although immigration policies have been the focus of increasing concern in Canada recently, it seems likely that the birthrate will continue to be the most important factor influencing future growth although recent pronouncements by the Minister of Immigration suggest the contrary.[1] However, it is a fact that the migration element lends itself more directly to political and administrative control than does natural increase.

SELECTION OF IMMIGRANTS

Admission to Canada as an immigrant is at present determined by the Immigration Act, 1952 as amended in 1966-1967 and 1967-1968 and by the Immigration Regulations formulated under the terms of that Act. The Act itself gives the Minister of Immigration extensive powers to regulate the criteria of selection and admissibility to Canada by Orders in Council. All persons admitted to Canada must pass a health check and they must not belong to one of the 'prohibited classes'. At present, these include various physical and mental disabilities, those with a criminal record, alcohol or drug addicts, potential subversive individuals or spies, etc. together with anyone who might become a public charge. It is expected that some of these provisions will be modified and liberalized when a new Immigration Act is introduced in the next Parliament. There is general agreement that the physical and mental health restrictions are too stringent in the light of recent advances in medical knowledge and that deportation for becoming a 'public charge' is anachronistic in the age of the 'welfare state'. Since 1967, the Regulations have distinguished independent immigrants, sponsored dependents and nominated immigrants. The category of 'refugee' cuts across the above classification and, in immigration statistics, refugees are included in one of of the above categories. However, special policies and procedures applied to the admission of refugees, and these will be discussed below, (c.I.P.s. 2: 99-118). 
Independent applicants are those prospective permanent settlers who expect to become self-supporting and successfully established in Canada by virtue of the skills, knowledge or other qualifications they possess. This category includes also the spouse and unmarried children less than 21 years of age, if they are assessed at the same time as the independent applicant. The regulations of 1967 established nine criteria against which independent applicants were assessed. These are summarized in Table 1, where the range of assessment for each category is indicated.

Education and training receives the greatest weight, up to 20 points for each year of formal education, apprenticeship, vocational, trades or professional training, successfully completed. There is some overlap between this category and that of 'occupational skill' which is assessed on a scale up to 10 points that the intended occupation itself is considered to require. Selection officers have the discretion of adding or subtracting one unit to reflect evidence of particularly high or low skill attained by the applicant. Another important criterion is 'occupational demand' which varies from time to time, and by region of Canada, according to information supplied from its offices across Canada to the Department of Manpower and Immigration. Age is another factor. It is generally assumed that there is a negative association between age of migration and adaptability. Therefore, applicants over 35 years lose one unit for each year of age up to a maximum of ten points, i.e. 45 years. Older immigrants may still be admitted so long as they are able to accumulate sufficient points on other criteria.

'Arranged employment' means that a definite job through a specific employer has been provided for the applicant, prior to admission to Canada. The employment must be long term and the working conditions and wages must be consistent with other similar employment in Canada. Since 1974, prospective immigrants are now awarded points in this category only when the Department of Manpower and Immigration certifies that suitably qualified Canadian citizens or permanent residents are not available to fill the jobs concerned. Closely related is the category 'designated occupation', also first introduced in 1974. Certain occupations are so designated when there is a persistent unfillable shortage in particular localities of Canada. Points will be earned only when the applicant indicates his willingness to take such employment in the specific area concerned. This factor is related to the 'area demand' factor which may earn up to an additional five points for those immigrants going to an area where job opportunities are most abundant. Further factors include an assessment of applicant's knowledge of English and/or French, together with a personal assessment by the selection officer of the personal qualities of the potential immigrant. Emphasis here is placed upon factors such as adaptability, motivation, initiative and resourcefulness, although the brief nature of the selection interviews makes this assessment a difficult one, in many cases. In the last resort and, subject to the concurrence of a designated senior officer, a selection officer may exercise discretion to approve a person who does not have enough points or to reject one who does, but this discretion is used very rarely. Finally, the law requires each independent applicant to have the means to maintain himself and his immediate family until he is established'. This means that independent immigrants must have some funds with them on arrival in Canada to assist them in the initial adjustment process. Depending upon the size of family and whether or not there is pre-arranged employment, the sum of money involved may range from $\$ 200$ to more than $\$ 1,000$, (C.I.P.s. 2: 49). 
Table 1. Summary of selection factors

Independent Applicants

$\begin{array}{r}\text { Long-Term Factors } \begin{array}{r}\text { Range of Units of } \\ \text { Assessment that } \\ \text { May be Awarded }\end{array} \\ \hline\end{array}$

Education and Training

0-20

Personal Qualities

Occupational Demand

Occupational Skill

Age

0-15

$0-15$

1-10

0-10

Short-Term Factors

Arranged Employment/Designated

Occupation

0 or 10

Knowledge of English and/or French 0-10

Relative in Canada

Area of destination

Potential maximum

0 or 3 or 5

0-5

100

\section{Nominated Relatives}

Long-term factors (as for independent

applicants)

$1-70$

Short-term settlement arrangements

provided by relative in Canada 15, 20, 25 or 30

Potential maximum

Sponsored Dependents

Close relative in Canada

willing to take responsibility

for care and maintenance
Notes

1. Independent Applicants and Nominated Relatives, to qualify for selection, must normally earn 50 or more of the potential 100 units of assessment. In addition they must have received at least one unit for the occupational demand factor or be destined to arranged employment or a designated occupation.

2. In unusual cases, selection officers may accept or reject an Independent Applicant for Nominated Relative nothwithstanding the actual number of units of assessment awarded. 3. Entrepreneurs are assessed in the same way as Independent Applicants except that they receive an automatic 25 units of assessment in lieu of any units they might have received for the occupational demand and occupational skill factors.

4. A change in the Regulations was made in October 1974. The Regulations now stipulate that, from the total points awarded either an independent or nominated applicant, 10 are deducted unless the applicant shows evidence of bona fide arranged employment, or is going to a job where persistent regional shortages are known to exist (i.e. a 'designated occupation.') The applicant will receive credit for arranged employment only when it has been established that no Canadian citizen or permanent resident is available to fill the vacancy.

Source: Department of Manpower and Immigration, (C.I.P.s. 2: 59-60).

Sponsored dependents include the close relatives of a Canadian citizen or landed immigrant in Canada. Such persons may sponsor the husband or wife; the fiancee; an unmarried son or daughter less than 21 years of age; a parent or grandparent 60 years of age or more (or younger if widowed or incapacitated); an orphan brother, sister, nephew, niece or grandchild less than 18 years of age; an unmarried adopted son or daughter less than 21 years of age, provided that the adoption took place before the 
child reached 18 years of age; an orphan, abandoned child or other child placed with a welfare authority for adoption, who is less than 13 years of age and whom the sponsor intends to adopt. In addition, a person who has no close relatives in Canada, and no relative abroad for sponsorship, may sponsor, once in his lifetime, one relative of any degree, to come to Canada and be with him as a companion, heir, etc. Apart from the health check, the sponsored immigrant does not have to meet any other requirements, but the sponsor in Canada must be at least 18 years of age and be capable of supporting the relative.

Nominated relatives are credited with up to a maximum of 30 units of assessment, according to the degree of closeness of the family relationship with the nominator, but must meet the other admission requirements on a similar basis to independent applicants. They may fall into any of the following categories: sons and daughters, irrespective of age or marital status (i.e. those not eligible to be considered as sponsored dependents); parents and grandparents less than 60 years of age); brothers and sisters (including half brothers and half sisters); grandchildren; uncles and aunts; nephews and nieces. In each case, a nomination includes the spouse and unmarried sons and daughters less than 21 years of age of the relatives named. Those nominating relatives to come to Canada must be more than 18 years of age and give an undertaking to provide care and maintenance to the nominated relatives, from his own resources, for a period of five years from the date of their arrival in Canada. In practice, most nominated immigrants will become eligible (by virtue of their own contributions) to unemployment insurance and other health and welfare benefits in Canada before the expiration of the five years. However, should they fail to do so, they would not be eligible for other forms of welfare assistance and the nominator would be expected to provide the necessary financial assistance. Theoretically, any immigrant may be deported from Canada for becoming a 'public charge'. In practice, this is a rarely enforced regulation, (C.I.P.s. 3: 98-101).

Between 1967 and 1972, Canada permitted visitors to Canada to apply for 'landed immigrant status' i.e. for permanent settlement, after arrival in Canada. While the majority of immigrants continued to go through the selection process and obtain the necessary documentation abroad, an increasing proportion took advantage of the opportunity to by-pass these selection processes, entering Canada as non-immigrants initially. In 1967, less than six per cent of all immigrants received the necessary approval for settlement after arrival, but by 1973, a third of all immigrants were processed administratively after arrival. Although permission to apply for permanent residence from within Canada was withdrawn in 1972, applications from people already in the country before that date were still being processed in 1975. The Canadian government was compelled to withdraw the privilege of applying for permanent residence after arrival, because the increasing number of people taking advantage of this procedure became administratively out of control and was causing injustice to those who applied from abroad, through the regular channels, (C.I.P.s. 2: 35-37). The situation was aggravated by the fact that, also in 1967, an appeal procedure against deportation had been instituted.

The Appeal Board was established on the assumption that the number of cases of deportation to be dealt with annually would be quite small. However, in practice visitors to Canada, who initially failed to qualify for permanent settlement, (because they did not accumulate enough points on the basis of education, occupation, etc.), appealed 
against deportation. Meanwhile, they remained in Canada and were permitted to seek employment, rather than become a public charge. By 1973, the number of appeals against deportation had risen to astronomical proportions and would have taken the tribunal up to ten years to deal with.[2] At this point, a special adjustment procedure was adopted, together with an amnesty for those who were in the country illegally. As a consequence, large numbers of people who had come to Canada as visitors were allowed to settle permanently on the basis of much less stringent criteria than those which had hitherto applied. Subsequently, new and stricter regulations were introduced which were designed to limit the number of people who would be eligible for admission to Canada as landed immigrants.

In order to understand the crisis which faced the Canadian immigration authorities in 1972, it is necessary to recognize the importance of tourism in the present day world economy. Canada, like many other countries today, has a substantial economic interest in the encouragement of tourism and in facilitating the movement of people into and out of the country for recreational and temporary business purposes, such as conventions of management or professional groups. Therefore, it is reluctant to impose upon airlines or other transportation companies, travel agents or the visitors themselves, the burden of too much bureaucratic control at the points of entry and exit. In 1972, non-resident travellers entering Canada numbered 38.2 million persons, more than the total population of the country! Of these, $\mathbf{3 7 . 2}$ million were from the United States and one million from all other countries. Residents of Canada re-entering from abroad totalled 33.0 million, indicating multiple journeys by many travellers. It is estimated that total receipts from the United States and other travellers entering Canada were over 1,200 million dollars! (Travel, 1974: 80). It is not surprising that the Government does not wish to offend the clients of such a lucrative industry. Canada does not have a system of alien registration. Neither the native or foreign-born population is required to notify any change of address or employment. Until recently it was comparatively easy for anyone, whether a visitor, a landed immigrant or even as an illegal resident to obtain a social insurance number. Such a number is a prerequisite for employment, but, until recently, employers had no obligation to ascertain whether a potential employee had permanent resident status or permission to obtain work in Canada.

Prior to 1972, independent immigrants were required to earn 50 or more of the potential 100 units of assessment. Special administrative measures in 1972 and an 'adjustment of status programme' in 1973 permitted many applicants in Canada to be given landed immigrant status on very much relaxed criteria. These measures were designed to clear up the backlog of applications and appeals in Canada. By the end of 1974, nearly 50,000 immigrants had been admitted (either in the independent or nominated categories) who would not normally have met the selection criteria. The distribution of immigrants to Canada 1968-1974, by admission category and labour force status, are shown in Table 2. It should be noted that the figures include some persons given permanent resident status after arrival in Canada, but exclude those on temporary employment visas.

Changes in regulations in February and October, 1974 imposed more stringent conditions of admission. No matter how many points for other reasons (age, education, destination) a would-be immigrant may receive, he or she cannot enter Canada as an immigrant at present unless they have either, (a) at least one 'point' for an occupation 
Table 2. Immigration* to Canada by category and labour force status 1968-1974

\begin{tabular}{|c|c|c|c|c|c|c|c|c|c|c|c|c|}
\hline \multirow[b]{2}{*}{ Year } & \multicolumn{3}{|c|}{ Labour Force } & \multicolumn{3}{|c|}{ Non-Labour Force } & \multicolumn{6}{|c|}{ Total } \\
\hline & $\begin{array}{l}\text { Spon- } \\
\text { sored }\end{array}$ & $\begin{array}{c}\text { Nomi- } \\
\text { nated }\end{array}$ & $\begin{array}{r}\text { Inde- } \\
\text { pendent }\end{array}$ & $\begin{array}{l}\text { Spon- } \\
\text { sored }\end{array}$ & $\begin{array}{l}\text { Nomi- } \\
\text { nated }\end{array}$ & $\begin{array}{r}\text { Inde- } \\
\text { pendent }\end{array}$ & $\begin{array}{l}\text { Spon- } \\
\text { sored }\end{array}$ & $\begin{array}{l}\text { Nomi- } \\
\text { nated }\end{array}$ & $\begin{array}{r}\text { Inde- } \\
\text { pendent }\end{array}$ & $\%$ & Number & $\begin{array}{l}\text { After } \\
\text { Arrival }\end{array}$ \\
\hline 1968 & 3.3 & 10.4 & 38.3 & 17.6 & 8.7 & 21.9 & 20.8 & 19.1 & 60.1 & 100 & 183,974 & 5.8 \\
\hline 1969 & 4.1 & 13.6 & 34.6 & 16.7 & 10.6 & 20.4 & 20.8 & 24.2 & 55.0 & 100 & 161,531 & 9.0 \\
\hline 1970 & 4.5 & 13.3 & 34.9 & 17.3 & 10.5 & 19.5 & 21.8 & 23.8 & 54.4 & 100 & 147,713 & 12.2 \\
\hline 1971 & 6.1 & 13.8 & 30.4 & 21.3 & 10.3 & 18.1 & 27.4 & 24.1 & 48.5 & 100 & 121,900 & 14.4 \\
\hline 1972 & 6.4 & 14.4 & 28.0 & 20.7 & 11.0 & 19.5 & 27.1 & 25.4 & 47.5 & 100 & 122,006 & 28.6 \\
\hline 1973 & 4.9 & 13.1 & 32.1 & 17.9 & 11.2 & 20.8 & 22.8 & 24.3 & $\$ 2.9$ & 100 & 184,200 & 33.9 \\
\hline 1974 & n.a. & n.e. & n.a. & n.a. & n.a. & n.a. & 24.8 & 24.4 & 50.8 & 100 & 218,465 & 20.2 \\
\hline
\end{tabular}

n.a. = not available.

* landed immigrants only, excluding temporary workers.

Source: Department of Manpower and Immigration (adapted from cIPS 3: Tables 3.4 and 5.5).

needed in Canada, or (b) willingness and ability to work in a 'designated occupation' (severe local shortage), or (c) arranged employment with a bona fide Canadian employer (if no Canadians are available). In addition, in every case, after totalling all the points to which an applicant is entitled, the immigration officer will deduct ten points unless the applicant has satisfactory evidence of arranged employment or is coming to a cdesignated occupation'. In other words, with these exceptions, the required number of points for admission to Canada has been raised from 50 to 60, (c.I.P.s. 2: 59-60).

These restrictive measures reflect, on the one hand, a deteriorating economic situation in Canada and the anticipated high unemployment in 1974 and 1975 and, on the other hand, the increasing potential supply of immigrants to Canada from many parts of the world.[3] The revived interest in migration to Canada, evident in 1973 and 1974, is itself a reflection of world demographic and economic conditions. It has been influenced in part by the reduced opportunity to emigrate to other traditional receiving countries, such as Australia, New Zealand and some countries in Europe, which have imposed limits on the number of permanent or temporary workers they will accept.

In addition to introducing more stringent regulations in 1974, the Department of Manpower and Immigration adopted administrative procedures to determine what it called 'global priorities'. Selection officers were instructed to give first priority to all applications for sponsored immigrants, i.e. immediate dependents of persons already in Canada. Second priority was given to independent and nominated immigrants destined to occupations in high demand. These were occupations earning eight points or more on the occupational demand scale or who had pre-arranged employment. Third priority was given to enterpreneurs expected to create employment in Canada by investing capital 
and starting their own business. Lowest priority was given to all other independent and nominated immigrants who came on a 'first come, first served' basis but after the higher priority categories had been dealt with. In practice, this will mean a slowing down in the flow of many independent and nominated immigrants to Canada. However, the new regulations, introduced in February and October, 1974, were not applied retroactively to potential immigrants who had already filed formal applications, although they were subject to the global priority scheme. As a consequence, the total number of immigrants approved for permanent residence in Canada in 1974 (including those who had first come to Canada as visitors) reached a near record total of 218,465 . Since the end of World War II, the only other years in which the number of immigrants admitted to Canada exceeded 200,000 were 1957 and 1967, (C.I.P.s. 3: 31). It is notable that these years were characterized by substantial refugee movements.

\section{Refugee Movements}

Since the end of World War 1, Canada has admitted more than a quarter of a million refugees. The large majority of these arrived in the first five years after the War. However, a series of international emergencies since then has resulted in a continued flow of refugees and of expellees who, while not technically refugees in terms of the United Nations definition, nevertheless have left the former country for reasons of political persecution. Since 1968, 16,320 refugees have been admitted to Canada, together with an additional 7,000 Asian expellees from Uganda. The largest single group were those from Czechoslovakia. In 1967 and 1968 a total of nearly 19,000 Czechoslovakian refugees was admitted. Other special movements in recent years have included 228 Tibetans and 1,400 persons from Chile, (c.I.P.s. 3: 46).

Despite the number of refugees admitted, Canada was slow to acceed to the U.N. convention on Refugees and did not do so until 1970. Provision is made for the admission of refugees who cannot meet the usual selection criteria so long as the authorities are satisfied that there is sufficient private or government assistance available in Canada to ensure successful establishment. For example, in 1973, 72 per cent of the 405 refugees were admitted on relaxed criteria and in 1974, 69 per cent of the 547 refugees admitted that year did not achieve the necessary units of assessment under the usual selection factors. In theory Canada has agreed to sponsor up to 50 handicapped refugees and their families, annually, in connection with the special Handicapped Refugees Programme of the U.N.H.C.R. In practice, the numbers admitted are generally much smaller. In 1973 and 1974, the combined total of handicapped refugees was only four! One of the obstacles to a more generous programme of admissions for handicapped immigrants is the necessity of cooperation between Federal and Provincial governments in Canada, together with the voluntary agencies. Nevertheless, the special arrangements made for the reception of refugees and expellees under emergency conditions, together with the special programmes designed to facilitate the social adjustment of such refugee movements, have provided organizational models which many people consider should be extended to the reception and services provided for all immigrants to Canada, (Hawkins, 1972: 369). Unfortunately, the expense of such programmes makes it unlikely that the government will be willing to provide the necessary funding on a permanent basis. 
The year 1967 was a major turning point in Canadian immigration. The introduction of the 'points' system of selection and the abolition of specific racial, ethnic and national criteria of preference resulted in a significant shift in the sources of immigration by country. The distribution of Canadian immigration offices abroad constituted the only residual basis of discrimination and this was modified with the opening of new offices in Asia, Africa and South America.[4] Although Britain continued to rank among the most important sources of immigration to Canada, the proportion coming from that country declined, from more than a quarter in 1946-1967, to less than 12 per cent in 1971 and subsequently recovered to nearly 18 per cent in 1974 . In part, the decline in British immigration was compensated by an increase in those coming from the United States. There has been a steady decline in the proportion from European countries. The latter constituted 56 per cent of all immigrants before 1967, but were only 23 per cent in 1974. The major increase has been in immigration from Asia, which has risen from less than four per cent to 23 per cent in 1974 and from the Caribbean and Central America which average three per cent before 1967 and was nearly 12 per cent in 1974 .

A high proportion of immigrants entering Canada each year have already made one or more previous international moves and are not coming directly from the country of birth. The percentage of persons immigrating from a country other than their own birthplace, or citizenship, varies from country to country.[5] When weighted by the actual size of immigration from these countries, it may be estimated that more than 12 per cent of all immigrants had previous experience of emigration. It must be remembered, also, that many immigrants re-migrate or return to the former country, after admission to Canada. Although exact figures are not available, 'settler loss' from Canada is probably close to 30 per cent which is probably higher than the Australian figure.[6] Return migration is particularly high to the United States and Great Britain. The transitory nature of international migration is further emphasized by the increasing use of temporary workers recruited abroad.

\section{Temporary Employment Visas}

Since 1972, Canada has instituted a system of temporary employment visas. These enable non-immigrants to be admitted to the country for a period up to 12 months for employment, without obtaining permission for permanent residence. Such employment visas are supposed to be issued only when the Department of Manpower and Immigration is satisfied that suitably qualified Canadian residents (Canadian-born or landed immigrants) are not available for the employment in question. The maximum period for which a temporary employment visa may be issued is 12 months; it is not know how many workers successfully apply for a renewal of the permit when it expires, but it is likely that many remain in Canada longer than 12 months.

In 1973 and 1974, the number of temporary employment visas came close to the total number of persons, admitted to the country for permanent residence, who intended to enter the labour force. (Approximately half the permanent immigrants admitted to the country each year are dependents, not immediately expected to enter the labour force). 
In 1973, 92,228 labour force immigrants were admitted (including those already in the country who were given landed immigrant status). This compares with 80,934 temporary employment visas issued that year. In $1974,87,353$ temporary employment visas were issued, compared with 106,083 immigrants who were destined to the labour force.

It is interesting to compare the countries of origin and the intended occupations of those admitted for permanent residence with those admitted on temporary employment visas. Whereas Britain and the United States almost tied for first place among the source countries for permanent immigration, the United States is the largest supplier of temporary workers. Great Britain is the second largest supplier, but falls considerably behind the United States in this respect. When Jamaica, Trinidad, Barbados and other Caribbean countries are combined, they exceed Britain in the proportion of temporary workers, but do not rank as high as suppliers of permanent immigrants. The residual 'others' category, which constitutes almost one-third of the temporary employment visas and almost half of those issued for ten months or more, includes a wide variety of countries. Among them are India, Pakistan, Haiti and some other Third World countries. Whereas the United States supplied two-thirds of those issued temporary employment visas for three months or less it was the country of origin of less than $20 \%$ of those issued for 10 months or more. This suggests that some employers and employees are utilizing the temporary employment visa system as a means of circumventing the regular immigration visa procedures.

No data have been made available by the Department of Manpower and Immigration cross-tabulating country of origin with occupation for those issued temporary employment visas. However, it would be reasonable to suppose that many of the workers from Third World countries on temporary employment visas would have difficulty in obtaining the necessary minimum number of points to qualify for landed immigrant status. At the same time, there is a demand, both continuing and seasonal, for relatively unskilled workers in the many industries and localities in Canada that it is difficult to fill with Canadians, or immigrants with permanent resident status. This is true despite relatively high levels of unemployment in Canada and appears to be due to the low wages, poor working conditions and remote areas in which such employment is available.[6] These factors make such employment unattractive, when unemployment insurance benefits and welfare services are available to the unemployed who have established entitlement through previous employment and insurance contributions.

Data are available which enable a comparison to be made between the intended occupational categories of permanent immigrants entering the labour force and those entering on temporary employment visas, in 1973 and 1974. (C.I.P.s. 3: 75). In the managerial category, (which includes enterpreneurs intending to establish their own business or a branch in Canada) there is little difference in the proportion approximately $6 \%$ of those entering as permanent immigrants and on temporary visas. This is true also of the professional fields; with the exception of teachers, where there is a high proportion on temporary visas. Some are probably on visiting or exchange appointments. The category described as 'artistic, literary and performing arts' has the highest proportion of temporary visas which reflects the large numbers of radio, television and theatrical performers who visit Canada for short periods. The clerical category has a much higher proportion of permanent immigrants as does 'fabricating, assembling and repairing', 
although nearly one in ten of temporary workers are also in this category. The seasonal nature of demand for farm labour is reflected in the high proportion of temporary workers in this category. (Twelve per cent temporary visas compared with $3 \%$ immigrants). Also subject to seasonal fluctuation is the tourist industry and this is indicated by the fact that 15 per cent of the temporary workers are in 'service' industries which include hotels, etc. However, service occupations are also well represented among permanent immigrants.

Care must be taken in the interpretation of the statistics of intended occupation for immigrants. The data for holders of temporary employment visas are probably more reliable as they are based on information concerning pre-arranged employment. However, various studies have indicated that the first employment in Canada of immigrants is often quite different from that in the former country and from that declared as the 'intended occupation' for the purpose of determining admissibility for permanent residence, (Richmond, 1967: 54). For example, a longitudinal study of a sample of the 1969 cohort of immigrants which has been followed up for three years, indicated that after one year in Canada, 61 per cent of the immigrants were employed in the intended occupation, (C.I.P.S. 4: 32). After two years, this proportion was 62 per cent and by the end of the third year, 69 per cent. In other words, after three years in Canada, almost a third of the immigrants were not employed in the intended occupation. The study excluded those who had re-migrated within the first three years, some of whom may have returned home precisely because they were unable to obtain the job they expected. Of those who remained and were not in the intended occupation, 44 per cent indicated that the reason was that their qualifications were not recognized, not accepted or that they lacked 'Canadian experience'. A further 21 per cent indicated that the intended job was not available when they arrived in Canada, and 16 per cent indicated that language problems had prevented them from obtaining the intended occupation, (c.I.P.s. 4: 33-34).

Greater differences between the national and occupational distributions of immigrants entering the labour force and holders of temporary employment visas may arise in the future. During 1973 and 1974, temporary employment visas were issued to some applicants in Canada who were seeking permanent residence, but whose applications were still in process. Of the temporary employment visas issued in 1973, 7,500 fell in this category. As it is no longer possible for non-immigrants in Canada to apply for permanent residence without leaving the country, the use of temporary employment visas for such a transitional period will not be necessary in future.

There are certain categories of people working temporarily in Canada who are exempt from the necessity of obtaining a temporary employment visa. They include certain sales representatives of foreign firms, officials inspecting a Canadian branch of a foreign company, visiting teams of athletes and large groups of performers (as distinct from individual artists), crews of foreign ships or aircraft, foreign news correspondents and, also, diplomats. For some other categories of visitors, it is comparatively simple to obtain an employment visa on arrival in Canada. They include students for whom work is an essential part of their studies, ministers of religion, teachers, small groups of entertainers, executives of subsidiary companies, medical interns, commuters from across the American border, together with other workers admitted for short periods under 
federally approved programmes. The people in these categories may be issued an employment visa at a port of entry, but other temporary workers must obtain employment visas in advance. These will not be issued if the Department of Manpower and Immigration considers that Canadian residents are available for the employment. By the same token, Canadian employers may arrange, through the Department of Manpower and Immigration, for workers to come from abroad on temporary visas if it can be shown that no qualified workers are available in Canada.

Some of the non-immigrant workers come under block movements approved by the Federal Government following an agreement between Canada and another country. Most of these movements involve agricultural workers. For example, the Caribbean Seasonal Workers Programme is governed by agreements between Canada and the governments of Jamaica, Barbados, Trinidad and Tobago. Employers must meet minimal standards of wages and accommodations and contribute to transportation costs. These workers are employed for a few months at the height of the agricultural harvest season in cropping or food canning operations. In 1974, a similar agreement was signed with the Government of Mexico to provide temporary harvest labour. There are also special movements of students and other young people to Canada during the summer months. Under these schemes, approximately 2,600 young people come to Canada annually for purposes other than academic training. Foreign students in Canada may not normally take jobs unless they qualify for employment visas in the same way as any other nonimmigrant. The major exception are those for whom employment forms an integral part of their course of study. However, students already in Canada, before the implementation of the Temporary Employment Visa scheme, have been permitted to obtain employment until the termination of their studies. In future, students will have to be self-supporting.

So far, Canada has avoided the worst abuses associated with the 'guest worker' system common in some European countries. However, there has been criticism of the inadequate housing, health and welfare services available to temporary workers. There is some concern regarding the consequences of bringing unattached male workers and the possible social problems that may be created in the future if the numbers were to increase substantially. Although there are some obvious benefits to non-immigrants who are allowed to work in Canada temporarily, there are also significant disadvantages. Generally speaking, non-immigrants pay taxes and contribute toward the costs of unemployment insurance and other social services, without deriving any benefit from these payments. Few of the countries concerned have reciprocal agreements with Canada which means they cannot collect social benefits after their return. Although some non-immigrants may have their temporary employment visas renewed, the system appears to be evolving into one of 'rotational employment' and is subject to the various criticisms that have been directed toward this system in Europe, (Böhning, 1974).

FUTURE PROSPECTS

In 1973 the Federal government instituted the Canadian Immigration and Population Study which led to the publication, in 1975, of a 'Green Paper' on immigration. Unlike a 
'White Paper', which is a statement of government policy, a 'Green Paper' is designed to provide a factual background and to stimulate public discussion of a major policy question, prior to the formulation of new legislation. The four volumes of the "Green Paper', together with a number of technical reports prepared by consultants and published separately, review Canada's experience of immigration in recent years in the light of contemporary demographic and economic conditions in Canada and abroad (C.I.P.s. $1-4,1975$ ). Final decisions on the policy issues raised will depend upon public reaction, expressed through briefs submitted to the government by many individuals and organizations, various local, regional and national conferences and the conclusions reached by a Joint Parliamentary Comnittee of the House of Commons and Senate. This Committee is reviewing the Cireen Paper and inviting further written and oral submissions. Eventually, it is expected that a new Immigration Bill will be laid before Parliament, and the direction of future policy determined, in the light of the facts and values that emerge from this unusual exercise in 'participatory democracy'. That immigration has been singled out for this kind of treatment implies that the government is not at all sure of the direction that future policies should take, but believes that the issues are highly sensitive politically.

The Green Paper suggests a number of issues where a new Act could offer solutions that present legislation does not afford. They include the question of deportation. It is suggested that, both on humanitarian grounds and in the interests of effective immigration management, a new Act could usefully provide alternative means of excluding people from Canada. Where circumstances justify such exclusion a means should be found that would not entail the stigma and consequences of deportation, as such. A further related question is that of the control and enforcement procedures in relation to the duration of residence of non-immigrants and the problem of illegal immigration. With the large numbers of people entering Canada daily and the increasing use of temporary employment visas, this problem has become crucial. Unlike many other countries, Canada has no registration procedures for change of address or other controls to circumscribe the freedom of movement of people born in or admitted to the country whether temporarily or permanently. Also related to questions of admission and deportation are the Special Inquiry system and the Immigration Appeal Board. The procedures of these bodies, which deal with persons not normally admissible on a permanent basis require revision in order to ensure that the highest standards of justice are maintained, and that appropriate humanitarian considerations are taken into account. It is also recognized that a new Immigration Act should contain explicit statutory recognition of refugee status and incorporate the obligations Canada now adheres to since acceeding to the United Nations convention on this subject.

Whatever changes may be made in the new Immigration Act, there will continue to be important policy decisions subject only to regulation and administrative procedure. In this connection, the Green Paper puts forward various options for the future. It is recognized that the proposals made are not mutually exclusive nor do they exhaust all the possible procedures that might be adopted. One option would be to maintain the existing system which does not involve determining, in advance, the number of visas which may be issued by Canadian immigration centres in various countries. Subject only to the capacity of the administration to handle the applications, all persons eligible in 
terms of the regulations at any given time would be allowed to go forward. Alternatively, the immigration programme could be geared more closely to economic conditions in Canada and labour market objectives. Among other things, this might mean abolishing the category of nominated immigrants who tend to experience more unemployment and greater difficulties in achieving satisfactory economic adjustment in the early years after arrival in Canada. It could also mean that the absolute number of immigrants admitted annually might be determined, in advance, in the light of demographic, economic and social conditions in Canada. Such explicit 'targets' for the number of visas to be issued annually, might be determined on a global basis, or by region or could be allocated country by country. This would amount to a quota system, similar to that of the United States, which Canada has not previously adopted.

Another possibility is that a global ceiling for the total immigration movement might be set annually, together with the priorities to be observed in terms of occupational demand, or other factors, in Canada, but without any regional or national quotas. Such a system would mean that, once the overall ceiling and priorities were established, an attempt would be made to ensure that the higher priority applicants in all countries were expedited. At the same time, some way would have to be found to ensure that lower priority applicants did not experience longer delays in some areas than in others, to avoid discrimination between nationals of different countries. It is too early to predict which of these alternatives, singly or in combination. will be adopted by the Canadian government. However, it is evident that in the long run, Canadian immigration policy will be a response to the internal dynamics of Canadian society as well as external demographic and political pressures. Political economic, demographic and social factors will interact with each other and the outcome is hard to predict with certainty.

Many Canadians feel themselves to be victims of American economic and cultural imperialism. They are sensitive to the quasi-colonial relationship which Canada has with the United States, due to the extensive American ownership of Canadian industry and the pervasiveness of American cultural values through the mass media. However, Canada is also an imperialist country in its own right. It is not only a wealthy country with vast resources, but its relationship with the Third World is just as exploitive as that of other western countries. From a sociological point of view, international migration must be placed in the broader context of the differential distribution of resources, capital and income both within and between countries.

Some economists and sociologists have suggested that the external investment policies of western capitalist countries, and so-called 'aid' to Third World countries, have simply increased dependency and systematically retarded development, (Frank, n.d.). As a result, a pool of surplus labour has been created which can be drawn into the economics of more advanced societies when required and quickly ejected again when no longer needed. It has been argued that, in order to understand questions of international migration today, attention must be paid both to forms of stratification, division of labour and conflict within the domestic metropolitan context and, also, to the patterns of social relations of the latter with dependent colonial and quasi-colonial societies. (Rex, 1973: 154).

Whether one accepts these interpretations or not, it is evident that the rapid growth of population in the Third World, combined with the relative lack of opportunities for 
occupational and social mobility in those countries, will create an increasing supply of people looking to emigration as a solution to their needs and ambitions. The scale of population growth throughout the world is such that the world population crisis cannot be solved merely by redistribution. Nevertheless, there will be pressure on more advanced countries, particularly those with low population densities such as Canada, to accept more immigrants. However, the economies and social systems of western societies are based upon assumptions of national sovereignty and the desire to maintain existing levels of wealth and privilege. Policies designed to reduce unemployment and maintain minimum levels of health and welfare involve some degree of economic and social planning, even in those countries dedicated to capitalism and free enterprise. The idea of a 'welfare state' necessarily implies some control over population and labour force growth. A completely uncontrolled flow of immigrants is out of the question if the economic and social stability of a modern society is to be maintained. At the same time, immigration itself is increasingly of a transilient and often rotational character.

Within the advanced countries upward social mobility, though the educational system, has created new aspirations and expectations which these countries are having difficulty in fulfilling for all their citizens. Traditionally, opposition to immigration came from the manual working classes who saw immigrants as sources of cheap labour, undermining the bargaining position of labour unions. However, an educationally selective immigration policy, such as that conducted by Canada in recent years, now threatens the middle classes and those who are upwardly mobile. Recent public opinion polls in Canada suggest that although higher education is still associated with a more favourable attitude toward immigration, there is less variation between the different education levels now than in the past. There has been a substantial drop in support by the University educated for the idea that Canada needs immigrants, (Tienhaara, 1975: 26). Clearly, there are many confiicting interests that the Canadian government must endeavour to reconcile as it formulates an immigration policy for the last quarter of the 20th century. Like most political decisions, the outcome will probably be an unsatisfactory compromise between long-run ideals and short-run economic interests.

\section{L'IMMIGRATION AU CANADA:}

\section{EVOLUTION RECENTE ET PERSPECTIVES D'AVENIR}

Le Canada compte 22 millions et demi d'habitants pour un territoire d'environ 10 millions de kilomètres carrés. C'est là une densité très faible, mais il convient de noter que la majeure partie de la population se trouve dans les régions proches de la frontière des Etats-Unis, et que dans cette partie du pays la densité de peuplement se rapproche davantage des normes européennes. Actuellement, la population canadienne est sept fois plus nombreuse et davantage qu'au moment du premier recensement, qui a eu lieu 
en 1871. Cette croissance s'explique à la fois par le taux de fécondité et par la progression du solde net de l'immigration. En 1973 le taux brut des naissances était inférieur au niveau de remplacement, mais peut-être cela signifie-t-il simplement que certains jeunes couples qui ne désiraient pas d'enfant pendant les premières années de leur mariage se montreront ensuite plus féconds. De 1961 à 1971 la part de l'immigration dans l'accroissement de la population a diminué par rapport à la décennie précédente; cependant son importance relative a quelque peu augmenté récemment, en raison du faible taux de natalité des dernières années.

On distingue parmi les immigrants ceux qui sont 'indépendants', ceux qui arrivent à la demande de proches parents et ceux qui sont 'appelés par des répondants'. Ceux de la dernière catégorie sont directement pris en charge par des personnes résidant déjà au Canada. De 1967 à 1972 le Canada a autorisé les titulaires d'un visa de touriste à demander l'octroi du 'statut d'immigrant sur place' en vue de l'installation permanente, mais cette disposition a été abrogée après 1972. Néanmoins, près d'un tiers environ des personnes qui ont obtenu le statut d'immigrant permanent depuis 1972 résidaient déjà au Canada à cette époque.

Avant 1972 on exigeait des immigrants qu'ils fournissent au moins 50 pour cent de réponses satisfaisantes à un questionnaire axé, en particulier, sur la connaissance d'une des langues officielles ou des deux langues, sur l'instruction, la profession etc. Depuis 1974, les immigrants indépendants doivent obtenir au moins 60 points sur 100, ou avoir un emploi assuré d'avance, ou encore accepter un emploi qui leur est affecté dans une région du Canada où la demande est suffisamment forte pour la profession considérée.

En dehors de l'immigration courante, le Canada a accueilli des réfugiés provenant de divers pays, notamment 19.000 réfugiés venant de Tchécoslovaquie, 7.000 Asiatiques chassés de l'Ouganda et 1.400 réfugiés du Chili.

Depuis 1972 le Canada a institué, en matière d'emploi, un système de visa pour emploi temporaire, qui permet aux non-immigrants d'être admis dans le pays pour y travailler pendant une période ne dépassant pas 12 mois. En 1974, on a délivré 87.353 visas pour emploi temporaire. Peut-être s'agissait-il en partie de renouvellements de visa, mais il est intéressant de rapprocher ce chiffre de celui de 106.083 immigrants admis dans le pays pour y travailler dans le cadre du programme normal d'immigration.

Un changement important est intervenu dans la composition ethnique de l'immigration au Canada depuis 1962, époque à laquelle on a cessé de prendre en considération toutes notions discriminatoires reposant sur le lieu de naissance, la race, ou la nationalité d'origine. La proportion des immigrants venus de Grande-Bretagne et d'Europe a régulièrement décliné. L'immigration en provenance de ces pays, qui jusqu'en 1967 fournissaient plus de 80 pour cent de la totalité des immigrants, a diminué pour s'établir à moins de 40 pour cent en 1974 . En revanche, l'immigration en provenance des pays d'Asie est passée de 4 pour cent en 1967 à 23 pour cent en 1974. Pour les Antilles et l'Amérique centrale, la proportion est passée de 3 à 12 pour cent.

Le Gouvernement canadien a publié au début de 1975 un 'Livre vert' où il expose les diverses options politiques de l'avenir, en matière d'immigration au Canada. Ces options ont fait l'objet de nombreux exposés dans des conférences qui se sont tenues dans tout le Canada, ainsi que dans la presse. Au nombre des possibilités figure l'adoption de contingents annuels globaux et de contingents régionaux, ainsi que l'instauration 
d'une politique d'immigration donnant la priorité aux objectifs démographiques plutôt qu'aux objectifs à court terme en matière d'économie et d'emploi, qui jusqu'ici étaient au centre des préoccupations.

Nombreux sont les intérêts divergents que le Gouvernement canadien doit s'efforcer de concilier en définissant sa politique d'immigration pour les vingt-cinq dernières années du vingtième siècle.

\section{LA INMIGRACION CANADIENSE:}

\section{NOVEDADES Y PERSPECTIVAS}

El Canadá tiene una población de 22.500 .000 personas que habitan un territorio de cerca de diez millones de $\mathrm{km}^{2}$. Aunque esto representa una densidad muy baja, la mayor parte de la población vive cerca de la frontera con los Estados Unidos, zona en la cual las densidades de población de las distintas Provincias, se aproximan más a las de Europa. La población del Canadá es hoy día más de siete veces mayor que la registrada en el primer censo, levantado en 1871. Han contribuido a ese aumento tanto la fertilidad como la inmigración neta. En 1973, la tasa bruta de reproducción había descendido por debajo del nivel de sustitución, pero esto puede no significar sino simplemente el aplazamiento de nacimientos por parte de matrimonios jóvenes y conducir a un cierto aumento de la fertilidad ulteriormente. La contribución de la inmigración al aumento de población bajó entre 1961 y 1971 en relación con la década anterior, aunque, debido a las recientes bajas tasas de natalidad, esa contribución haya registrado un cierto aumento porcentual en los últimos tiempos.

Los inmigrantes está clasificados en tres categorias: 'independientes', 'propuestos por parientes próximos' y 'patrocinados'. Estos últimos son personas directamente a cargo de los que ya han establecido su domicilio en el Canadá. Entre 1967 y 1972, el Canadá permitía a los visitantes al pais que solicitasen el denominado 'Landed immigrant status', es decir, la residencia permanente, pero esta disposición dejó de estar en vigor a partir de 1972. Sin embargo, casi un tercio de los admitidos como residentes permanentes en el Canadá desde 1972 residian ya en el país en el momento de la admisión.

Antes de 1972, los inmigrantes independientes estaban obligados a obtener 50 a más de un total posible de 100 'unidades de evaluación' en una estimación que atribuía sobre todo importancia al conocimiento de uno o ambos idiomas oficiales, la educación, la demanda de duerza laboral y otros factores semejantes. Desde 1974, los inmigrantes independientes necesitan por lo menos 60 unidades de evaluación y/o un empleo previo; si no reúnen esas condiciones, están obligados a aceptar la ocupación que se les asigne en una zona del Canadá en la que haya demanda para esa ocupación.

Además de la corriente normal de inmigrantes, el Canadá ha admitido a refugiados de diversos países, entre los que figuran 19.000 de Checoslovaquia, 7.000 asiáticos expulsados de Uganda y 1.400 personas procedentes de Chile.

Desde 1972, el Canadá ha instituido un sistema de visados temporales de empleo. 
Tales visados permiten a los no inmigrantes ser admitidos para trabajar en el país durante un periodo de hasta doce meses. En 1974, se expidieron 87.353 visados temporales de empleo. Algunos de los casos comprendidos en esa cifra pueden haber sido renovaciones, pero cabe comparar esa cifra con la de 106.083 inmigrantes normales destinados a integrar la fuerza de trabajo.

Desde 1962, se ha producido un cambio importante en la composición étnica de la inmigración canadiense; en ese año quedaron eliminadas de los reglementos de admisión todas las discriminaciones basadas en el lugar de nacimiento, la raza o el origen nacional. Ha habido una continua disminución de la proporción de inmigrantes procedentes de la Gran Bretaña y del continente europeo. Antes de 1967, la inmigración desde esos países constituía más del 80 por ciento de la inmigración total; en 1974, esa proporción era inferior al 40 por ciento. La inmigración procedente de paises asiáticos aumentó de menos del 4 por ciento antes de 1967 al 23 por ciento en 1974. La proporción de los inmigrantes procedentes de América Central y de la región del Caribe pasó del 3 al 12 por ciento.

A principios de 1975, el Gobierno canadiense publicó un 'Libro Verde' en el que exponía posibilidades alternativas para la política futura de inmigración del Canadá. Esas posibilidades alternativas se han discutido ampliamente en muchas conferencias reunidas en todo el país, y en la prensa. Entre ellas figuran la de adoptar cuotas globales anuales y cuotas regionales, y la de dar mayor importancia a los fines demográficos en la política de inmigración, en vez de fijar a corto plazo objetivos económicos y de fuerza laboral, lo que habia tendido a constituir hasta ahora el foco principal de esa política. Hay muchos intereses contrapuestos que el Gobierno canadiense tiene que esforzarse por conciliar al formular su política de inmigración para el último cuarto del siglo xx.

\section{NOTES}

1. In a speech by Mr. Robest Andras, Minister of Manpower and Immigration in Vancouver, April 13, 1975 it was suggested that 'In 1973, net immigration accounted for just under half the total population growth and in 1974 it is expected to have accounted for just about half of total population growth.' However, these calculations appear to be based on an under-estimation of the scale of emigration from Canada and do not allow for the fact that a significant proportion of those given landed immigrant status in those years were already in the country as visitors or temporary workers.

2. In a Parliamentary address on the second reading of an Act to amend the Immigration Appeal Board Act on June 20,1973, the Minister of Manpower and Immigration stated that the backlog of appeals against deportation had increased at the rate of 1,000 a month and had reached a total of over 17,000, while the capacity of the Board to handle cases was only 100 a month. The new legislation was designed to eliminate the backlog by special adjustment procedures and more lenient admission criteria, for those whose cases were pending; the Act also increased the capacity of the Board to deal with future appeals promptly. At the same time, the right of appeal against deportation in Canada was revoked for all those who were not already landed immigrants in Canada or in possession of immigrant or non-immigrant visas, issued abroad, when they arrived. 3. The increased interest in migration to Canada was reflected in the number of pre-application 
enquiries and questionnaires completed at Canadian immigration offices abroad. According to official sources, there were 122,476 such enquiries in 1974, which was a 46 per cent increase over the previous year. Due to the stringent criteria being adopted, 76 per cent of these were discouraged by immigration officers and did not result in a formal application for admission to Canada being submitted. Actual applications increased by 36 per cent and totalled 239,411 in 1974 . The number of immigrant visas issued by the end of 1974 had increased by 42 per cent over the previous year, and there was an increase of 37 per cent in the number of applications still in process, by the end of the calendar year.

4. In 1966, Canada had 122 immigration officers posted abroad, of whom 93 were in Britain and Europe, 12 in the United States, 4 in the Middle East and 13 in Asian countries. By 1974, there were 174 officers of whom 86 were in Britain and Europe, 25 in the United States, 15 in the Caribbean, Central and South America, 14 in Africa and the Middle East, 30 in Asian countries and 4 in Australia, (c.I.P.s. 3: 107-109).

5. For example, of those who gave Britain as the country of last permanent residence, 16 per cent were not born there and 10 per cent were not citizens of that country. The figures for Belgium were 47 per cent and 44 per cent respectively; Hong Kong 48 per cent and 47 per cent; United States 17 per cent not the same birthplace and 7 per cent not citizens of the United States.

6. Because Australia pays an assisted passage for many immigrants, the government has ben more concerned than has Canada with the question of return migration. Estimates of settler loss from Australia vary according to the method of calculation. (Price, 1971: A105). The best estimate for the period 1966-1970 is approximately 23 per cent of foreign born permanent settlers. 7. In a speech at the annual meeting of the Ontario Lumber Manufacturers' Association, in April 1975, the Minister of Manpower and Immigration warned employers against relying on temporary workers from abroad and suggested that, when Canadian employers could not fill jobs or suffered from a high turnover of workers, his Department 'found that unfilled jobs are mostly in those industries which are characterized by one or more such factors as low wages, poor working conditions, remote location, few social amenities, poor supervisory practices or an absence of decent living accommodation.'

\section{BIBLIOG RAPHY}

BöHNING, W. R., 'Immigration Policies of Western European Countries,' International Migration Review, 1974 (8), 2: 155-164.

Canada Year Book (1973), Minister of Industry Trade and Commerce and Information Canada, Ottawa, 1973.

c.I.P.S. 1, Immigration Policy Perspectives, Department of Manpower and Immigration and Information Canada, Ottawa, 1975.

c.I.P.s. 2, The Immigration Programme, Department of Manpower and Immigration and Information Canada, Ottawa, 1975.

C.I.P.S. 3, Immigration and Population Statistics, Department of Manpower and Immigration and Information Canada, Ottawa, 1975.

c.I.P.s. 4, Three Years in Canada: First Report of the Longitudinal Survey on the Economic and Social Adaptation of Immigrants, Department of Manpower and Immigration and Information Canada, Ottawa, 1975.

Census of Canada (1971), Advance Bulletin, AP-9, Population by Birthplace, Statistics Canada and Information Canada, Ottawa, 1974. 
Frank, A. G., The Sociology of Underdevelopment and the Underdevelopment of Sociology, Copenhagen, n.d.

Hawkins, F., Canada and Immigration: Public Policy and Public Concern, McGill-Queen's University Press, Montreal, 1972.

KalbaCh, W. E. and W. W. McVeY, The Demographic Basis of Canadian Society, McGraw-Hill, Toronto, 1971.

Kubat, D. and D. Thornton, A Statistical Profile of Canadian Society, McGraw-Hill Ryerson, Toronto, 1974.

Price, C. A., Australian Immigration: A Bibliography and Digest, No. 2, Australia National University, Canberra, 1971.

Rex, J., Race, Colonialism and the City, Routledge and Kegan Paul, London, 1973.

Rrchmond, A. H., Post-War Immigrants in Canada, University of Toronto Press, Toronto, 1967.

TenntaArA, N., Canadian Views on Immigration and Population, (Canadian Immigration and

Population Study), Department of Manpower and Immigration and Information Canada, Ottawa, 1975.

Travel Between Canada and Other Countries, (1972), Statistics Canada and Information Canada, Ottawa, 1974. 